Plant Tissue Cult. \& Biotech. 19(1): 1-7, 2009 (June)

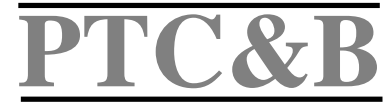

\title{
In vitro Propagation of Vanda testacea (Lindl.) Reichb.f. - A Rare Orchid of High Medicinal Value
}

\author{
Saranjeet Kaur ${ }^{1}$ and K.K. Bhutani \\ Department of Natural Products, National Institute of Pharmaceutical Education and \\ Research, Mohali - 67, Punjab - 160 062, India \\ Key words: In vitro, Orchid, Vanda testacea, Micropropagation, Protocorm-like \\ bodies, Callus
}

\begin{abstract}
Foliar explants of Vanda testacea (Lindl.) Reichb. f. were cultured on Mitra (M) medium with $1.0 \mathrm{mg} / \mathrm{l} \mathrm{BAP}, \mathrm{Kn}$ each and $1.0 \mathrm{mg} / \mathrm{l}$ NAA individually and in combination for initiation of regeneration response, proliferation of regenerants and subsequent development of plantlets. Juvenility of the tissues and chemical stimulus were important factors in initiating the regeneration response in the explants. The relatively older leaf explants $(>1 \mathrm{~cm}$ in length) remained recalcitrant to regeneration the representing younger ones $(<1 \mathrm{~cm}$ in length) responded to certain chemical regimes. BAP, Kn individually in the medium should direct PLB regeneration whereas when used with NAA, the explants showed callus proliferation and further differentiated into PLBs. An individual treatment with NAA $(1.0 \mathrm{mg} / \mathrm{l})$ impaired the response frequency and delayed further morphogenetic processes leading to plantlet development. The best response in the explants (in terms of high regeneration frequency, early initiation, PLB proliferations, and plantlet development) was observed in $1.0 \mathrm{mg} / \mathrm{l}$ BAP alone/with $1.0 \mathrm{mg} / \mathrm{l} \mathrm{NAA}+$ activated charcoal. Plantlets were transferred to pots containing epiphytic compost (1 charcoal : 1 brick pices : 1 bats). Nearly $75 \%$ of plantlets survival was recorded.
\end{abstract}

\section{Introduction}

Vanda testacea (Lindl.) Reichb. f. (= V. parviflora Lindl.) known as Banda or Rasna, an alkaloid rich epiphytic species of vandaceous orchids, is widely known for its medicinal properties. Almost all plant parts (roots, leaves, flowers) in powder form or as an extract are used as herbal medicines to cure rheumatism, bronchitis, nervous disorders, piles, inflammations and also as a potential anticancerous drug (Chauhan 1990). This medicinally important orchid is faced with extensive collections and habitat destruction pressures. As a consequence its populations are depleted, the species has become rare and is restricted to very narrow pockets in its natural habitats. Herbal medicines are the precursors of

${ }^{1}$ Corresponding author: <sarana_123@rediffmail.com>. 
many common drugs prescribed in clinical practice in many countries today. Furthermore, herbs and herbal products are still an important part of the primary health care systems in many parts of the world (Jawahar et al. 2008a). Medicinal plants are of great interest to the researches in the field of biotechnology as most of the drug industries depend, in part, on plants for the production of pharmaceutical compounds (Chand et al. 1997). In vitro culture techniques offer a viable system for true-to-type rapid mass multiplication and germplasm conservation of rare, endangered, threatened, aromatic and medicinal plants (Arora and Bhojwani 1989, Sharma et al. 1991, Sudha and Seeni 1994, Sahoo and Chand 1998, Karuppusamy and Pullaiah 2007, Jawahar et al. 2008b).

Vanda testacea has a low rate of multiplication under natural/greenhouse conditions and like other monopodial orchids survival of mother plant is not conducive to a shoot tip/meristem based micropropagation system. It is thus necessary to device a rapid and efficient micropropagation protocol for obtaining true-to-type regenerants without detriment to the survival of mother/donor plant and saving its populations from getting rarer in nature. Ever since Morel (1960) suggested the use of shoot meristem culture, the technique has been applied in a large number of species to mass propagate them. Since the technique requires sacrifice of the only growing point in monopodial taxa, the utility of leaf explants is being increasingly realized as its excision does not endanger the growth and survival of the mother plant. In fact, significant number of identical clones can be raised from a single leaf through direct or callus mediated organogenesis (Arditti 1977). The regenerative potential of leaf explants has been positively tested in several orchid species representing diverse habits, habitats and taxonomic affinities (Tanaka and Sakanishi 1977, Fu 1978, 1979, Manorama et al. 1984, Mathews and Rao 1985a,b, Yam and Weatherhead 1991, Seeni and Latha 1992, 2000, Vij et al. 1994, Misra and Bhatnagar 1995, Kaur and Vij 2000, Vij and Aggarwal 2003, Tamjensangba and Deb 2005, Deb and Temjensabgba 2007). Presently, this communication reports the foliar explants based efficient in vitro propagation of Vanda testacea - a rare medicinal orchid species.

\section{Material and Methods}

Vanda testacea (Lindl.) Reichb. f. (= V. parviflora Lindl.) leaves $(1.0 \mathrm{~cm}$ long) sourced from 38 weeks old axenic cultures were used as explants. Mitra et al. 1976 (M) medium containing $2 \%$ sucrose was used as a source of nutrition. The medium was invariably gelled with $0.9 \%$ Agar powder (Qualigens). Individual and combined effects of plant growth regulators $\mathrm{Kn}, \mathrm{BAP}$ and NAA were also assessed on culture initiation and various morphogenetic processes. In another set of experiments, $2 \%$ activated charcoal (AC) was consistently used in the 
medium. The $\mathrm{pH}$ of medium was adjusted to 5.7 and autoclaved at $121^{\circ} \mathrm{C}$ at a pressure of $1.06 \mathrm{~kg} / \mathrm{cm}^{2}$ for $15 \mathrm{~min}$. The inoculations were done under aseptic conditions in a laminar air flow cabinet. Cultures were incubated at $25 \pm 2^{\circ} \mathrm{C}$ under $12 \mathrm{hr}$ photoperiod of 3,500 lux light intensity (Flourescent tubes-40W; Philips India Ltd., Mumbai, India). The experiments were repeated twice. The observations were made regularly and data recorded accordingly. The results were tested using the one-way ANOVA test and were analyzed using Tukey Multiple Comparison using SPSS (Version 11.5) software package.

\section{Results and Discussion}

Presently, the in vitro regeneration potential of foliar explants was positively tested in Vanda testacea. Culture initiation was markedly affected by the physiological status (juvenility) of tissues besides the chemical stimulus in the nutrient pool. Explants of more than $1.0 \mathrm{~cm}$ long leaves, remained recalcitrant to regeneration and those from less than $1.0 \mathrm{~cm}$ responded to certain selected media combinations. Juvenility of leaf tissues as an important factor promoting regeneration has been suggested in several orchids (Fu 1978, Vij and Pathak 1990, Arditti and Ernst 1993, Kaur and Vij 2000, Vij and Aggarwal 2003, Temjensangba and Deb 2005).

A better morphogenetic potential of juvenile (less differentiated) cells has been explained on the basis of their physiologically and biochemically more active state due to their less rigid cell walls (Misra and Bhatnagar 1995). In earlier experiments, apical and/or basal leaf segments were considered as meristematic loculae (Yam and Weatherhead 1991). Mathews and Rao (1985a,b) considered the leaf base as a decisive factor for regeneration in Vanda cultures. On the other hand, the tip region regenerated infrequently when excised and more frequently in an intact leaf. Almost similarly, the leaf base exhibited a greater proliferative potential than leaf tips in Ascocenda and Vanda (Fu 1978, 1979), Coelogyne, Dendrobium, Oncidium and Phalaenopsis (Abdul and Hairani 1990), Renanthera (Seeni and Latha 1992), and Acampe (Nayak et al. 1997).

In our present studies only the basal segments responded in cultures. This differential response of the juvenile leaves hints at the possibility of the influence of the genotype or the intrinsic factors of the mother plant upon regeneration potential. The study also determined the probability of control of meristematic potential by some factors emerging from the of leaf base tissues.

In our cultures, the explants regenerated along the adaxial surface only, in accord with similar earlier findings in Acampe praemorsa (Nayak et al. 1997) and Renanthera imschootiana (Seeni and Latha 1992). Literature studies also indicate activation of meristematic loci on both the adaxial and abaxial surfaces in some species (Manorama et al. 1984, Vij and Pathak 1990, Kaur and Vij 2000). 

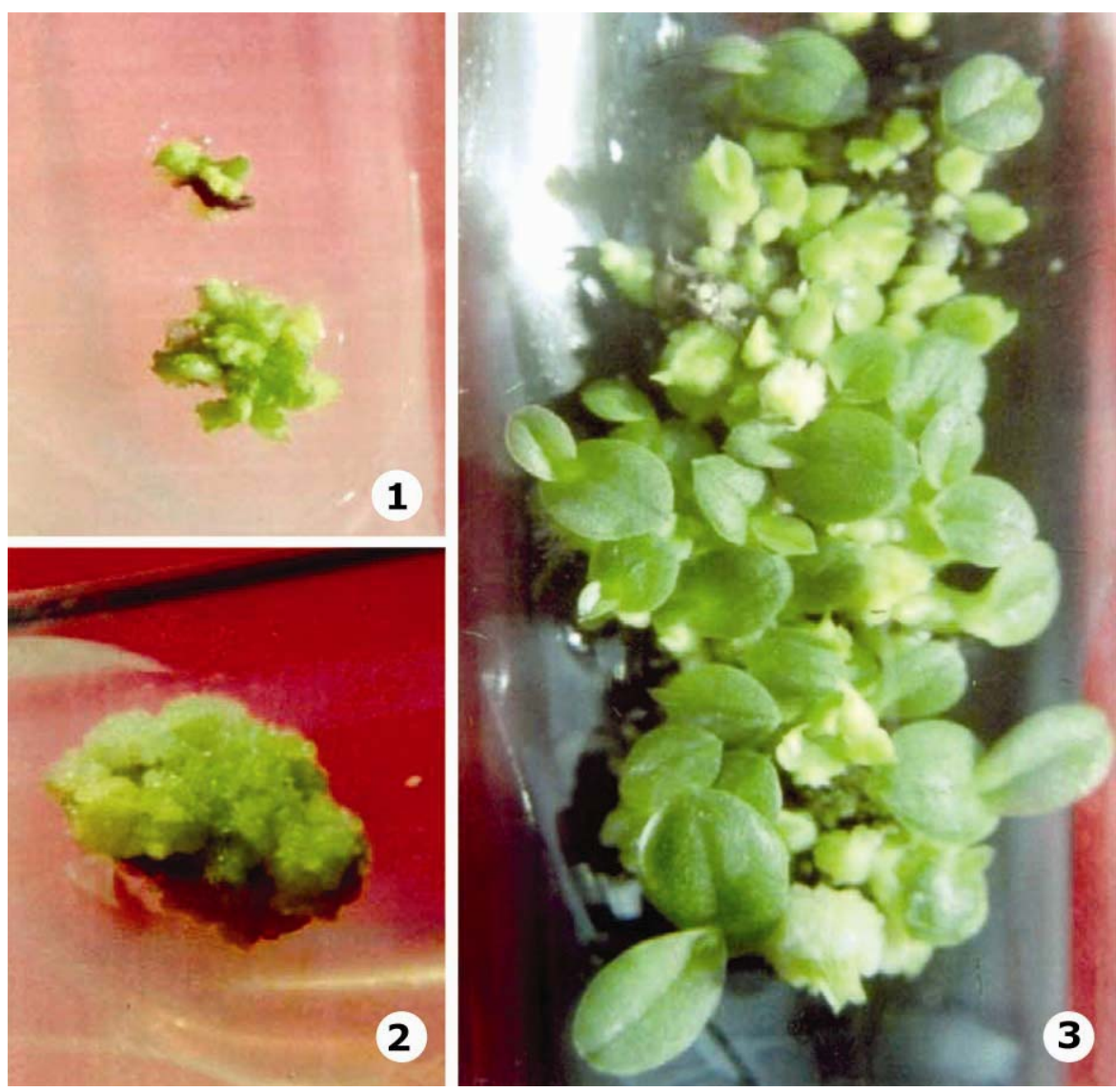

Figs. 1 - 3: In vitro regeneration response of foliar explants of Vanda testacea. 1. PLB mediated regeneration response in $\mathrm{M}+\mathrm{BAP} 1.0 \mathrm{mg} / \mathrm{l}$. 2. Differentiation of callus into PLBs in M + BAP $1.0 \mathrm{mg} / \mathrm{l}+$ NAA $1.0 \mathrm{mg} / \mathrm{l} .3$ Plantlet formation in M + BAP $1.0 \mathrm{mg} / \mathrm{l}+$ NAA1.0 mg/l +AC.

The role of growth adjuncts in initiating the meristematic activity in foliar explants and/or promoting proliferations thereof is well documented in orchids (Abdul and Hairani 1990, Arditti and Ernst 1993, Vij et al. 1994, Kaur and Vij 2000, Temjensangba and Deb 2005, Deb and Temjansangba 2007). In our studies, the regeneration response in the explants was completely dependent to the use of growth regulators in the culture medium (Table 1). BAP alone and with NAA were successfully used to enhance the regeneration frequency, early initiation of response and multiplication of regenerants, the explants followed PLB mediated and callus mediated pathway of regeneration respectively in the combinations (Figs.1, 2). Plantlets complete with two - three leaves and one - two roots developed within 20 - 25 weeks in activated charcoal supplemented medium (Fig. 3). The indispensability of cytokinins for regeneration of PLBs and multiplication thereof have been reported earlier in orchids (Vij et al. 2000). A 
synergistic action of cytokinins and auxins is reported in several orchid species e.g. Phalaenopsis (Tanaka and Sakanishi 1977), Vanda hybrid (Mathews and Rao 1985 a, b), Vanda criststa (Vij et al. 1994), Saccolabium papillosum (Kaur and Vij 2000) Cymbidium hybrid (Vij and Aggarwal 2003). The percentage of responding explants was significantly impaired in NAA treated cultures; even the morphogenetic processes leading to plantlet development were also prolonged delaying the formation of complete plantlets to 25 weeks. The explants followed callus mediated development of PLBs in the responding explants. Earlier also in Cleisostoma racimeferum NAA proved poor for regeneration (Temjensangba and Deb 2005).

Table 1. In vitro regeneration response of foliar explants of Vanda testacea in Mitra (M) medium and its combinations with growth adjuncts.

\begin{tabular}{lcccc}
\hline Additives & $\begin{array}{c}\text { \% regeneration } \\
\text { response }\end{array}$ & $\begin{array}{c}\text { Initiation of } \\
\text { response } \\
\text { (weeks) }\end{array}$ & $\begin{array}{c}\text { Regeneration } \\
\text { pathway }\end{array}$ & $\begin{array}{c}\text { Complete } \\
\text { plantlets } \\
\text { (weeks) }\end{array}$ \\
\hline- & $0.00^{\mathrm{a}}$ & $0.00^{\mathrm{a}}$ & - & $0.00^{\mathrm{a}}$ \\
$\mathrm{AC}$ & $0.00^{\mathrm{a}}$ & $0.00^{\mathrm{a}}$ & - & $0.00^{\mathrm{a}}$ \\
$\mathrm{BAP}$ & $48.75^{\mathrm{g}}$ & $4.75^{\mathrm{f}}$ & $*$ PLB-pl & $23.25^{\mathrm{i}}$ \\
$\mathrm{BAP}+\mathrm{AC}$ & $42.5^{\mathrm{d}}$ & $4.25^{\mathrm{f}}$ & $\prime$ & $23.00^{\mathrm{i}}$ \\
$\mathrm{Kn}$ & $42.25^{\mathrm{d}}$ & $5.00^{\mathrm{fi}}$ & $\prime$ & $23.75^{\mathrm{i}}$ \\
$\mathrm{Kn}+\mathrm{AC}$ & $43.00^{\mathrm{d}}$ & $5.50^{\mathrm{fi}}$ & $\prime$ & $22.75 \mathrm{~g}$ \\
$\mathrm{NAA}$ & $38.50^{\mathrm{c}}$ & $7.25^{\mathrm{bcdi}}$ & $\mathrm{C}-\mathrm{PLB}-\mathrm{pl}$ & $25.25^{\mathrm{g}}$ \\
$\mathrm{NAA}+\mathrm{AC}$ & $24.25^{\mathrm{bi}}$ & $5.50^{\mathrm{i}}$ & $\prime$ & $26.00^{\mathrm{efhi}}$ \\
BAP + NAA & $48.75^{\mathrm{g}}$ & $3.75^{\mathrm{f}}$ & $* \prime$ & $21.75^{\mathrm{g}}$ \\
BAP + NAA + AC & $48.75^{\mathrm{g}}$ & $3.00^{\mathrm{defg}}$ & $* \prime$ & $20.25^{\mathrm{bcdg}}$ \\
\hline
\end{tabular}

Concentration of PGRs $=1.0 \mathrm{mg} / \mathrm{l}$ each; $\mathrm{C}=$ callus; PLB = Protocorm-like body; ${ }^{*}=\mathrm{PLB}$ multiplication; $\mathrm{pl}=$ Plantlet. Values in a column with similar superscripts are not significantly different at $\mathrm{p} \leq 0.05$.

All these data suggest that the initiation of meristematic activity in foliar explants is directly related to the juvenility of the donor tissues besides the chemical stimulus to which they are subjected. In general, the proximal segments respond better than distal ones. A careful selection of donor leaf (juvenile ones) and use of precise chemical stimulus can help devising an ideal propagation system without any detrimental effect to the mother plant. This protocol is simple and easy to carry for mass propagation and conservation of this rare valuable species. 


\section{Acknowledgement}

The authors are thankful to the authority of the Department of Biotechnology, Government of India, New Delhi for financial assistance to SA during the course of the present investigation.

\section{References}

Abdul Karim AG and Hairani H (1990) Leaf culture of some Malaysian orchids. In: Proc. International conference and exhibition on orchids and ornamental plants. Niar $\mathrm{H}$. (ed.) 12-17. The Orchid Society of Malaysia, Petaling Jeya, Malaysia.

Arditti J (1977) Clonal propagation of orchids by means of tissue culture - a manual. In: Arditti J (ed.), Orchid Biology Reviews and Perspectives, Vol. 1: 203-293. Cornell University Press, Ithaca and London.

Arditti J and Ernst R (1993) Micropropagation of Orchids. John Wiley, New York.

Arora R and Bhojwani SS (1989) In vitro propagation and low temperature storage of Saussurea lappa C.B. Clarke - An endangered medicinal plant. Plant Cell Rep. 8: 44-47.

Chand S, Sahrawat AK and Prakash DVSSR (1997) In vitro culture of Pimpinella anisum L. (anise). J. Plant Biochem. Biotech. 6 : 1-5.

Chauhan NS (1990) Medicinal orchids of Himachal Pradesh. J. Orchid Soc. India. 4(1,2): 99-105.

Deb CR and Temjensangba T Deb CR (2007) Direct regeneration of shoot buds in Arachnis labrosa foliar explants J. Orchid Soc. India 21(1,2): 7-9.

Fu FML (1978) Clonal propagation of Aranda, Ascocenda, and Cattleya by leaf tissue culture. Gard. Bull. Singapore 31: 132-138.

Fu FML(1979).Studies on tissue culture of orchids. Clonal propagation of Aranda, Ascocenda, and Cattleya by leaf tissue culture. Orchid Rev. 87:343-346.

Jawahar M, Ravipaul S and Jeyaseelan M (2008a) In vitro regeneration of Vitex negundo L.- a multipurpose woody aromatic medicinal shrub. Plant Tissue Cult. \& Biotech. 18(1): 37-42.

Jawahar M, Karthikeyan AVP, Vijai D, Maharajan M, Ravipaul S and Jeyseelan $\mathbf{M}(2008 b)$. In vitro plant regeneration from different explants of Cardiospermum helicacabum L. International Journal of Biology and Chemical Sciences 2(1): 14-20.

Karuppusamy S and Pullaiah T (2007) In vitro shoot multiplication of Bupleurum distichophyllum Wight. A native medicinal plant of southern India. Plant Tissue Culture and Biotechnology 17(2): 115-124.

Kaur Saranjeet and Vij S P(2000). Regeneration potential of Saccolabium papillosum leaf segments. J. Orchid Soc. India 14(1-2): 67-73.

Manorama P, Rao AN, Goh CJ and Loh CS (1984) Leaf callus development and organogenesis in Aranda and Dendrobium. In: Proc.5 Asean orchid congress seminar. Rao AN (ed.), 102-109. Photoplates Pte.ltd., Singapore.

Mathews VH and Rao PS (1985a) In vitro culture of Vanda hybrid (Vanda TMA $\times$ Vanda Miss Joaquim) I. Studies of protocorm explants. In: Proc. Indian Natl. Sci. Acad. 51(1): 96-103. 
Mathews VH and Rao PS (1985b) In vitro culture of Vanda hybrid (Vanda TMA $\times$ Vanda Miss Joaquim) II Studies on seedling explants. In: Proc. Indian Natl. Sci. Acad. 51(4): 496-504.

Misra AK and Bhatnagar SP (1995) Direct shoot regeneration from leaf explants of cucumber (Cucumis sativus L.). Phytomorph. 45: 47-55.

Mitra GC, Prasad RN and Chowdhury A Roy (1976). Inorganic salts and differentiation of protocorms in seed callus of an orchid and correlated changes in its free amino acid content. J. Exp. Biol. 14: 350-351.

Morel G M (1960). Producing virus free cymbidiums. Am. Orchid Soc. Bull. 29: 495-497.

Nayak NR, Patnaik S and Rath SP (1997) Direct shoot regeneration from leaf explants of epiphytic orchids Acampe praemorsa (Roxb.) Blatter and McCann. Plant Cell Rep. 16(8): 583-586.

Seeni S and Latha PG (1992). Foliar regeneration of the endangered Red Vanda, Renanthera imschootiana Rolfe (Orchidaceae). Plant Cell Tiss. Org. Cult. 29(3): 167-172.

Seeni S and Latha PG (2000). In vitro multiplication and ecorehabilitation of the endangered Blue Vanda. Plant Cell Tiss. Org. Cult. 61: 1-8.

Sahoo Y and Chand PK (1998). Micropropagation of Vitex negundo L. a woody aromatic medicinal shrub through high frequency of axillary shoot proliferation. Plant Cell Rep. 18: 301-307.

Sharma N, Chandel KPS and Srivastava VK (1991). In vitro propagation of Coleus forskohlii Briq. a threatened medicinal plant. Plant Cell Rep. 10: 67-70.

Sudha GC and Seeni (1994). In vitro multiplication and field establishment of Adhatoda beddomei C.B. Clarke - A rare medicinal plant. Plant Cell Rep. 13: 2003-2007.

Tanaka M and Sakanishi Y (1977). Clonal propagation of Phalaenopsis by leaf tissue culture. Am. Orchid Soc. Bull. 46(8): 733-737.

Temjensangba T and Deb CR (2005). Regeneration of plantlets from in vitro raised leaf explants of Cleisostoma racimeferum Lindl. Indian J. Exp. Biol. 43: 377-381.

Vij SP and Pathak P (1990).Micropropagation of orchids through leaf segments. J. Orchid Soc. India. 4(1,2): 69-88.

Vij SP and Aggarwal S (2003). Regenerative competence of foliar explants. J. Orchid Soc. India 17(1,2): 73-78.

Vij SP, Sharma V and Kaur Saranjeet (1994) Foliar explants and orchid micropropagation: Vanda Kasem's Delight Tom 'Boykin'. J. Orchid Soc. India 8(1,2): 79-83.

Vij SP, Kher Anoopama and Gupta Ashish (2000). Orchid micropropagation. In: Chadha KL. Ravindran P N, Saahijram Leela. (eds.), Biotechnology in Horticultural and Plantation Crops, 598-641. Malhotra Printing House, New Delhi, India.

Yam TW and Weatherhead M A (1991). Leaf-tip culture of several native orchids of Hong Kong. Lindleyana 6: 147-150 